\title{
PENDIDIKAN KARAKTER ISLAM DALAM KELAS BAHASA INGGRIS DI UNIVERSITAS WAHID HASYIM SEMARANG
}

\author{
Ulya Himawati, Nurul Azizah \\ Dosen Universitas Wahid Hasyim \\ Email: Ulyahimawati@unwahas.ac.id \\ Email: nuza_azizah@unwahas.ac.id
}

\begin{abstract}
Character education in Islam is commonly known as moral education. This moral education has been introduced by Allah SWT through the behavior of the Prophet Muhammad. at Islamic-style universities such as Wahid Hasyim University. A university that does not only focus on science but also instills the Islamic character of Ahlussunah Wal Jama'ah in order to support the hard skills and soft skills of its students to prepare for the needs and competition in the future era. This study explores how to apply or implement Islamic character education in English classes. It is known that English is a universal language. The language is owned by the west, so that language will indirectly be affected by western culture. Therefore, the mission of Wahid Hasyim University is Ahlussunah Wal Jama'ah and considers the morals of the Prophet, researchers combine these characters to find out how far the use of Islamic character education at Wahid Hasyim University. The result of this research is that lecturers have implemented Islamic character education in English class. So that students get Islamic character in the classroom that is in line with the mission of the university.
\end{abstract}

Keywords: Islamic Character Education, English Class

Abstrak

Pendidikan karakter dalam islam biasa dikenal dengan pendidikan akhlak. Pendidikan akhlak tersebut sudah diperkenalkan oleh Allah SWT melalui perilaku Rasulullah SAW. pada universitas bercorak islami seperti Universitas Wahid Hasyim. Universitas yang tidak hanya berfokus pada ilmu pegetahuan semata namun juga menanamkan karakter islami Ahlussunah Wal Jama'ah guna menunjang kemampuan hardskill serta softskill mahasiswanya untuk mempersiapkan kebutuhan dan persaingan pada era mendatang. Penelitian ini mengupas tentang bagaimana penerapan atau implementasi pendidikan karakter islam dalam kelas bahasa Inggris. Diketahui bahwa bahasa Inggris adalah bahasa universal. Bahasa yang dimiliki oleh barat, sehingga bahasa tersebut akan secara tidak langsung akan terpengaruh oleh budaya barat. Oleh karenanya, misi universitas wahid 
hasyim yang Ahlussunah Wal Jama'ah dan mempertimbangkan akhlak dari Rasulullah, peneliti menggabungkan karakter tersebut untuk mengetahui seberapa jauh penggunaan pendidikan karakter Islam pada universitas wahid hasyim. Hasil dari penelitian ini adalah dosen telah menerapkan pendidikan karakter Islam dalam kelas bahasa Inggris. Sehingga mahasiswa mendapatkan karakter islam dalam kelas yang sejalan dengan misi universitas.

Kata kunci : Pendidikan Karakter Islam, Kelas Bahasa Inggris

\section{A. Latar Belakang}

Pendidikan karakter menjadi trending topik yang paling sering dibicarakan akhir-akhir ini. Banyak peneliti yang mengembangkan tema pendidikan karakter untuk dijadikan bahan penelitian. Hal ini disebabkan adanya pengaruh sikap berbeda dari mahasiswa ketika dalam proses pembelajaran di kelas tidak disertakan nilai-nilai atau penanaman pendidikan karakter tersebut. Selain itu, karakter merupakan hal krusial dimana akhir-akhir ini semakin dirasakan efeknya dalam berbagai aspek kehidupan. Karakter bangsa secara sistemik terus luntur dan berakibat dalam kehidupan keseharian masyarakat. Kecurangan tidak lagi dirasakan sebagai hal yang perlu dihindari namun menjadi hal biasa, dimana kecurangan tersebut dilakukan tanpa ada rasa malu. Pelanggaran hukum dalam kehidupan berbangsa juga begitu terasa seperti seorang koruptor yang tertangkap tangan masih dapat tersenyum lebar di depan kamera media.

Begitu pula dengan siswa mencontek, persekusi, perusakan, kejahatan seksual dan lain sebagainya. Hal tersebut begitu mudah ditemukan dalam media elektronik maupun cetak. Rusaknya kontrol sosial masyarakat tidak lagi dapat menjadi benteng tanpa celah untung menanggulangi, justru terjadi pembiaran seolah suatu hal lumrah dalam masyarakat. Hal tersebut diperparah dengan penegakan hukum dimana legitimasinya masih dipertanyakan. Sebuah ironi dimana dunia 
pendidikan menjadi kambing hitam yang menjadi sebab hal tersebut terjadi atas gagalnya pendidikan karakter di sekolah. Dikarenakan hal tersebut, pemerintah memformulasikan kurikulum yang mana pendidikan karakter kembali menjadi salah satu fokus guna menanggulanginya. Berbagai wacana dikemukakan untuk menyisipkan pendidikan karakter di kurikulum sekolah. Tidak kalah juga pada level universitas, dimana pemerintah melihat bibit radikalisme menyebar dikalangan mahasiswa dapat dihentikan dengan adanya pendidikan karakter islami yang sesuai dan berdasarkan konstitusi yang berlaku. Sejalan dengan prinsip sebagai agama yang mengedepankan rahmatan lil alamin dimanapun pasti menolak segala bentuk kekerasan karena merupakan agama yang membawa rahmat dan kesejahteraan bagi seluruh alam semesta.

Menurut Zamroni Dalam usaha menghadapi tantangan perkembangan zaman ini dibutuhkan pendidikan yang berwawasan global, pendidikan yang memiliki nilai lentur terhadap perkembangan zaman namun muatan nilai-nilai moral keagamaan tetap terpatri di dalamnya. ${ }^{1}$ Isu pendidikan karakter memang sangat menarik untuk dijelaskan lebih dalam dari berbagai sudut pandang yang berbeda. Presiden Joko Widodo melalui Gerakan Nasional Revolusi Mental (GNRM) menangani serius pendidikan karakter tersebut, sehingga presiden mengeluarkan Peraturan Presiden Republik Indonesia Nomor 87 Tahun 2017 tentang Penguatan Pendidikan Karakter. ${ }^{2}$ Selanjutnya

\footnotetext{
${ }^{1}$ Zamroni, Paradigma Pendidikan Masa Depan, Jogjakarta: Gigraf Publishing, 2000, hlm. 90-91.

${ }^{2}$ Dalam rangka mewujudkan bangsa yang berbudaya melalui penguatan nilai-nilai religius, jujur, toleran, disiplin, bekerja keras, kreatif, mandiri, demokratis, rasa ingin tahu, semangat kebangsaan, cinta tanah air, menghargai prestasi, komunikatif, cinta damai, gemar membaca, peduli lingkungan, peduli sosial, dan bertanggung jawab, perlu penguatan pendidikan karakter. Lihat Peraturan Presiden Republik Indonesia nomor 87 tahun 2017 tentang Penguatan Pendidikan Karakter (PPK)
} 
peraturan presiden ini diwujudkan oleh Kementerian Pendidikan dan Kebudayaan dengan program 18 nilai pengembangan pendidikan budaya dan karakter bangsa. ${ }^{3}$ Oleh karenanya pendidikan karakter sangat penting bagi generasi sekarang ini untuk menciptakan sumber daya manusia yang santun dan berakhlak mulia. Ari Budiman sudah menyederhanakan nilai 18 karakter tersebut menjadi 5 poin sederhana; (1) Religius, (2) Nasionalis, (3) Mandiri, (4) Gotong Royong, (5) Integritas. ${ }^{4}$ Selebihnya, pendidikan karakter juga sangat penting bagi dunia pendidikan. Pendidikan karakter dalam islam biasa dikenal dengan pendidikan akhlak. Pendidikan akhlak tersebut sudah diperkenalkan oleh Allah SWT melalui perilaku Rasulullah SAW. Rasul di hadirkan ke muka bumi untuk menyempurnakan karakter atau akhlak manusia yang tercermin dalam surat Q.S Al-Ahzab ayat 21 yang artinya:

Sesungguhnya telah ada pada (diri) Rasulullah itu suri teladan yang baik bagimu (yaitu) bagi orang yang mengharap (rahmat) Allah dan (kedatangan) hari kiamat dan dia banyak menyebut Allah.

Selanjutnya pada universitas bercorak islami seperti Universitas Wahid Hasyim. Universitas yang tidak hanya berfokus pada ilmu pegetahuan semata namun juga menanamkan karakter islami Ahlussunah Wal Jama'ah guna menunjang kemampuan hardskill serta softskill mahasiswanya untuk mempersiapkan kebutuhan dan persaingan pada era mendatang. Karakter tersebut menunjang mahasiswa untuk tidak hanya berfokus pada hasil akhir yaitu pribadi cerdas, namun

\footnotetext{
${ }^{3}$ Penguatan nilai-nilai religius, jujur, toleran, disiplin, bekerja keras, kreatif, mandiri, demokratis, rasa ingin tahu, semangat kebangsaan, cinta tanah air, menghargai prestasi, komunikatif, cinta damai, gemar membaca, peduli lingkungan, peduli sosial, dan bertanggung jawab. Sumber Tim penyusun, Pelatihan Penguatan Metodologi Pembelajaran Berdasarkan Nilai-nilai Budaya untuk Membentuk Daya Saing dan Karakter Bangsa, oleh Pusat Kurikulum Departemen Pendidikan Nasional, 2010.

${ }^{4}$ Dr. Arie Budhiman, 2017, Gerakan Penguatan Pendidikan Karakter, Kementerian Pendidikan dan Kebudayaan Republik Indonesia, slide 18.
} 
mengarahkan mereka untuk menjadi agen perubahan dalam dirinya hingga sekitarnya. Sejalan dengan prinsip NU yang telah merumuskan beberapa prinsip dalam hal mengantisipasi persoalan sosial keagamaan, yaitu tasamuh (toleran), tawazun (seimbang/harmoni), tawasut (moderat), ta'adul (keadilan), dan amar ma'ruf nahi munkar (El- mawa, 2018). ${ }^{5}$ Gagasan Islam Nusantara menjadikan sebuah hasil budi khas bangsa Indonesia. Sebuah kesimpulan yang nyata berdasarkan data filologis dimana sejak dahulu konsep keislaman nusantara telah menafsirkan ajaran sesuai konteks tanpa adanya konfrontasi dan penolakan dalam kehidupan masyarakat.

Mempertimbangkan hal tersebut, urgensi semakin nyata atas pengimplementasian pendidikan karakter tersebut guna merevitalisasi tatanan kehidupan masyarakat untuk mengembalikan karakter bangsa yang berpersperktif multi kultur karena diasumsikan sebagai sebuah kunci mendasar pemecahan berbagai persoalan bangsa. Pendidikan merupakan langkah nyata dan terencana guna mengubah dan mempengaruhi manusia untuk mengembangkan potensi yang ada, sehingga pendidikan menjadi sebuah alat yang mempunyai daya gedor, daya tahan dan dampak nyata.

Seperti diketahui, Universitas Wahid Hasyim adalah universitas yang berangkat dari nilai-nilai islami ahlussunah wal jama'ah. Sehingga nilai-nilai islami perlu diterapkan di segala sudut yang ada di universitas wahid hasyim, khususnya pembelajaran yang ada dikelas. Bukan hanya budaya luar kelas saja yang diterapkan untuk pendidikan karakter islam, namun juga penting dalam pembelajaran di kelas untuk membantu mahasiswa terbiasa akan penggabungan pembelajaran dengan pendidikan karakter islam tersebut.

\footnotetext{
${ }^{5}$ Elmawa 2018
} 
Berdasarkan uraian tersebut, peneliti ingin meneliti lebih lanjut pengaplikasian nilai karakter pada level universitas. Secara khusus penelitian ini ditujukan bagi para mahasiswa yang belajar mata kuliah umum bahasa Inggris. Peneliti menganalisa penyisipan nilai karakter pada saat perkuliahan bahasa Inggris dilaksanakan. Penelitian ini diharapakan dapat memberikan manfaat sebagai referensi bagi para dosen di PTKI dalam menekankan kembali pendidikan karakter kepada mahasiswa.

\section{B. Kerangka Teori}

\section{Karakter}

Karakter berasal dari kata Kharakter yang asal katanya kharassein, sebuah kata di bahasa Yunani berarti mengukir. Bahasa Indonesia juga memiliki kosa kata karakter yang bermakna sifat, watak, tabiat (Narwanti, 2011). ${ }^{6}$ Menurutnya, karakter adalah kepribadian yang ternilai sehingga tidak bisa jika dikatakan sekedar kepribadian semata. Karakter tersebut menjadi penentu individu untuk berfikir dan bertingkah laku yang bermuara pada tingkah laku manusia pada tingkat yang lebih tinggi.

Pada kesempatan lain, Muslich mengutip keterangan Simon Philip mengenai karakter, karakter adalah kumpulan tata nilai yang menuju pada suatu sistem yang melandasi pemikiran, sikap dan perilaku yang ditampilkan. Begitu pula dalam kutipan selanjutnya menurut Prof. Suyanto menjelasakan bahwa karakter merupakan cara pikir dan berperilaku yang khas pada individu untuk hidup dan bekerjasama dalam lingkungan keluarga, masyarakat dan bangsa. ${ }^{7}$

6Masnur Muslich, 2011. Pendidikan Karakter Menjawab Tantangan Krisis Multidimensional, Jakarta: Bumi Aksara.

7ibid 
Dari berbagai keterangan di atas dapat disimpulkan bahwa karakter berkorelasi pada moral yang bersifat positif. Tidak ada sifat negatif yang dikandung dalam pengertian sebuah karakter. Dengan kata lain seseorang yang dikatakan berkarakter adalah orang yang mempunyai moral positif. Bila berbicara mengenai karakter dalam pendidikan akan bermuara pada upaya membangun pola perilaku yang berkaitan degan dimensi moral positif saja. ${ }^{8}$

Disamping itu, Undang Undang Republik Indonesia Nomor 20 Tahun 2003 tentang sistem pendidikan nasional merumuskan tujuan dari pendidikan karakter ini. Yang berbunyi sebagai berikut:

Sistem pendidikan nasional menyataka bahwa pendidikan nasional berfungsi mengembangkan kemampuan dan membentuk watak serta peradaban bangsa yang bermartabat dalam rangka mencerdaskan kehidupan bangsa, bertujuan untuk berkembangnya potensi peserta didik agar menjadi manusia yang beriman dan bertakwa kepada Tuhan Yang Maha Esa, berakhlak mulia, sehat, berilmu, cakap, kreatif, mandiri dan menjadi warga negara yang demokratis serta bertanggung jawab.

Tujuan tersebut ditujukan untuk membangun kualitas manusia Indonesia dalam dunia pendidikan, khususnya dilaksanakan oleh satuan pendidikan. Dengan kata lain satuan pendidikan mempunyai tanggung jawab untuk membangun pola perilaku anak didiknya untuk menjadi dasar dalam pengembangan pendidikan karakter dan budaya bangsa. Diharapkan dengan adanya hal tersebut dapat membantu individu untuk mempersiapkan kemampuannya dalam hal bekerjasama di lingkungan keluarga, masyarakat, bangsa dan juga membantu untuk dapat mengarahkan 
mereka dalam mengambil keputusan yang dapat dipertanggung jawabkan.

\section{Fungsi Dan Tujuan Pendidikan Karakter}

Menurut Hasan (2010), fungsi dari pendidikan karakter adalah sebagai berikut;

a. Pengembangan: pengembangan potensi peserta didik untuk menjadi pribadi berperilaku baik. Ini ditujukan bagi peserta didik yang telah memiliki sikap dan perilaku yang mencerminkan budaya dan karakter bangsa.

b. Perbaikan: memperkuat kiprah pendidikan nasiona untuk bertanggung jawab dalam pengembangan potensi peserta didik yang lebih bermartabat.

c. Penyaring: digunakan untuk menyaring budaya bangsa sendiri dan budaya bangsa lain yang tidak sesuai dengan nilai budaya dan karakter bangsa yang bermartabat.

Disamping itu, Hasan (2010) juga menjelasakan mengenai fungsi dari pendidikan karakter islami, diantaranya adalah;

a. Mengembangkan potensi kalbu peserta didik sebagi manusia dan warga negara yang memiliki nilai-nilai karakter dan budaya bangsa.

b. Mengembangkan kebiasaan dan perilaku peserta didik yang terpuji dan sejalan dengan nilai-nilai universal dan tradisi budaya bangsa yang religius.

c. Menanamkan jiwa kepemimpinan dan tanggung jawab peserta didik sebagai generasi penerus bangsa

d. Mengembangkan kemampuan peserta didik menjadi manusia mandiri, kreatif, berwawasan kebangsaan 
e. Mengembangkan lingkungan kehidupan sekolah sebagai lingkungan belajar yang aman, jujur, penuh kreativitas dan persahabatan serta dengan rasa kebangsaan yang tinggi dan penuh kekuatan (dignity).

\section{Pendidikan Karakter Islam}

Menurut Hamid dan saebani (2013) dalam Islam, karakter identik dengan akhlak. Khuluqun merupakan asal muasal kata akhlak dalam bahasa Indonesia atau akhlaq dalam bahasa Arab. Khuluqun adalah bentuk singular, sedangkan akhlaq adalah bentuk jamaknya. Kata - kata tersebut mempunyai arti budi pekerti, tingkah laku, tata krama, sopan santun, adab. Disamping itu kata akhlak juga ada yang berakar kata pada khalaqa yang mempunyai makna kejadian.

Menurut alwi (2010) kata Islami mempunyai makna bersifat keislaman, mempunyai nilai Islam. Sedangkan bila dirunut pada KBBI, mempunyai arti bersifat keislaman, yaitu menyandarkan sesuatu pada Islam yang berdasar pada Al Quran dan Al Hadist. Hal ini berarti segala sesuatu berlandaskan pada prinsip-prinsip Islam.

Dengan adanya pengertian tersebut, dapat disimpulkan bahwa pendidikan karakter Islam adalah usaha untuk merubah dan membangun tingkah laku, budi pekerti, tata krama, sopan santun, adab berdasarkan pada prinsip-prinsip Islam sehingga bermuara pada perbuatan yang sesuai dengan aturan Islam. Perbuatan yang sesuai aturan Islam sendiri tidak dapat berdiri sendiri tanpa adanya keimanan. Menurut Fitri dkk (2010) iman adalah maknawi sedangkan akhlak adalah bukti keimanan dalam bentuk perbuatan yang dilakukan dengan kesadaran dan karena Allah semata. 
Akhlak, keteladanan dan adab adalah tiga nilai utama dalam Islam. Menurut Majid dan Andayani (2013) akhlak bermakna tanggung jawab diluar syari'ah dan ajaran islam secara umum. Adab adalah sikap yang berkorelasi pada tingkah laku, dan keteladanan adalah kualitas karakter mengikuti keteladanan Nabi Muhammad SAW.

Menurut Muhammad Yaumi (2014) nilai luhur islami terdiri atas beriman dan bertaqwa, jujur, amanah, adil, bertanggung jawab, berimpati. Namun, pendidikan karakter Islam yang akan diterapkan dalam pembelajaran bahasa inggris adalah pendidikan karakter Rasullullah SAW yang bersifat sidiq, amanah, tabligh, dan fatonah. Sehingga nantinya karakter Islami yang dicontohkan Rasulullah SAW dapat diimplementasikan oleh mahasiswa Universitas Wahid Hasyim Semarang.

a. Sidiq; artinya benar. Bukan hanya perkataannya yang benar, tapi juga perbuatannya juga benar.

b. Amanah; Merupakan sikap jujur dan dapat diandalkan dalm menjalankan komitmen, tugas, dan kewajiban. Disamping itu terkandung sikap jujur dan integritas.

c. Tabligh; menyampaikan. mempunyai pengertian bahwa rasulullah selalu menyampaikan segala sesuatu yang diwahyukan Allah kepadanya.

d. Fatonah; cerdas dan intelek.

Selanjutnya, demi mengajarkan nilai-nilai karakter yang baik, yang sesuai dengan ajaran agama yang Sejalan dengan prinsip NU yang telah merumuskan beberapa prinsip dalam hal mengantisipasi persoalan sosial keagamaan, yaitu tasamuh (toleran), tawazun (seimbang/harmoni), tawasut (moderat), ta'adul (keadilan), 
dan amar ma'ruf nahi munkar (El-mawa, 2018). ${ }^{9}$ Peneliti memasukkan ke 5 nilai karakter Ahlussunah Wal Jama'ah ke dalam penelitian ini. Hal ini sesuai dengan misi Universitas Wahid Hasyim yang menerapkan Ahlussunah Wal Jama'ah sebagai ciri khas atau karakter universitas.

Penggabungan antara ajaran Rasullullah SAW dan misi universitas untuk lebih mengenalkan karakter Islam yang diajarkan Rasullullah tanpa mengesampingkan misi universitas. Sehingga pembelajaran bahasa Inggris dalam kelas bahasa Inggris yang diterapkan adalah pembelajaran akhlak Rasulullah dan Ahlussunah Wal Jama'ah. Sehingga terbentuklah tabel seperti dibawah ini.

\section{Tabel 1}

\section{Pendidikan Karakter Islam}

\begin{tabular}{|c|l|l|}
\hline No & \multicolumn{1}{|c|}{ Keterangan } & \multicolumn{1}{|c|}{ Uraian } \\
\hline 1 & Sidiq & $\begin{array}{l}\text { Benar, bukan hanya perkataan yang } \\
\text { benar, namun perbuatannya juga } \\
\text { harus benar }\end{array}$ \\
\hline 2 & Amanah & $\begin{array}{l}\text { Merupakan sikap jujur dan dapat } \\
\text { diandalkan dalm menjalankan } \\
\text { komitmen, tugas, dan kewajiban. } \\
\text { Disamping itu terkandung sikap jujur } \\
\text { dan integritas. }\end{array}$ \\
\hline 3 & Tabligh & $\begin{array}{l}\text { Menyampaikan. } \\
\text { pengertian bahwa rasulullah selalu } \\
\text { menyampaikan segala sesuatu yang } \\
\text { diwahyukan Allah kepadanya. }\end{array}$ \\
\hline
\end{tabular}

\footnotetext{
${ }^{9}$ Elmawa 2018
} 
Jurnal Pendidikan Agama Islam Universitas Wahid Hasyim

\begin{tabular}{|c|l|l|}
\hline 4 & Fatonah & Cerdas dan intelek \\
\hline 5 & Tasamuh (Toleran); & $\begin{array}{l}\text { Menghargai perbedaan orang lain. } \\
\text { Khususnya keaneka ragaman } \\
\text { Agama, suku, dan bahasa. }\end{array}$ \\
\hline 6 & $\begin{array}{l}\text { Tawazun } \\
\text { (Seimbang/Harmoni) }\end{array}$ & $\begin{array}{l}\text { Melakukan aktivitas dan hal yang } \\
\text { seimbang. Seperti tidak makan } \\
\text { terlalu banyak, tidak terlalu benci } \\
\text { terhadap orang lain dst. }\end{array}$ \\
\hline 7 & Tawasut (Moderat); & Tidak keras dan tidak lembek. \\
\hline 8 & Ta'adul (Keadilan); & $\begin{array}{l}\text { Mampu berlaku adil dalam setiap } \\
\text { pekerjaan yang dilakukan. }\end{array}$ \\
\hline 9 & $\begin{array}{l}\text { Amar ma'ruf nahi } \\
\text { Mungkar; }\end{array}$ & $\begin{array}{l}\text { Menjalankan perintah dan menjauhi } \\
\text { larangan. }\end{array}$ \\
\hline
\end{tabular}

Tabel 1.1 menjelaskan tentang penggabungan antara sifat Rasullullah SAW dengan Ahlussunah Wal Jama'ah. Sehingga terciptanya misi yang sesuai yang diinginkan oleh universitas. Sehingga dalam pembelajaran kelas bahasa Inggris terdapat pendidikan karakter Islami yang disesuaikan kebutuhan Universitas.

\section{Kelas Bahasa Inggris}

Bahasa sebagai alat manusia untuk mengekspresikan pikiran dan perasaannya. ${ }^{10}$ Sehingga bahasa dianggap sebagai sistem untuk berkomunikasi dengan orang lain, dengan menggunakan bunyi, simbol dan kata-kata untuk mengekspresikan makna, ide atau pikiran. Bahasa dapat diekspresikan melalui banyak bentuk,

\footnotetext{
${ }^{10}$ Saddhono, K. 2014. Pengantar Sosiolingistik Teori dan Konsep Dasar. Surakarta: UNS Press. Hlm.4
} 
terutama melalui komunikasi lisan dan tulisan serta menggunakan ekspresi melalui tubuh bahasa.

Bahasa merupakan sebuah alat utama yang kita perlukan untuk membuka dunia. ${ }^{11}$ Sebagai bahasa internasional, bahasa Inggris dituturkan dalam banyak dunia internasional dan digunakan sebagai media untuk informasi tentang pendidikan, sains, teknologi, budaya, dll. Menyadari pentingnya bahasa Inggris, pemerintah memberikan ruang tersendiri terhadap bahasa inggris untuk di ajarkan dari jenjang terendah sampai tertinggi. Sehingga dalam universitas, bahasa Inggris diletakkan sebagai mata kuliah umum untuk para mahasiswa pada semester awal, guna memberikan mahasiswa wawasan dan bekal untuk keberlangsungan perkuliahan.

Selanjutnya bahasa adalah bagian budaya dari sebuah negara. Sehingga bahasa menjadi identitas tersendiri bagi bangsa tersebut. Sehingga budaya barat sudah melekat pada bahasa Inggris ini. Dengan demikian untuk memberikan sentuhan yang berbeda dan untuk memberikan pendidikan karakter yang sesuai dengan Indonesia yang mayoritas penduduknya beragama Islam, bahasa Inggis tentunya harus diberikan sentuhan yang Islami agar karakter bangsa Indonesia berbeda dari bangsa Eropa.

Oleh karena itu, pendidikan karakter islam ini patut untuk diteliti dalam kalangan mahasiswa yang notabene belajar pada universitas yang menjunjung tinggi kaidah Islami, namun tidak mengesampingkan perbedaan bangsa.

\footnotetext{
${ }^{11}$ Inoko Hikmasari, 2012, Pemahaman Bahasa Inggris oleh siswa Kampung Inggris, JurnalUniversitas Unair, Vol.1, No. 1 Januari-Juni, hlm.4,http://journal.unair.ac.id/download-fullpapersjurnal\%20skripsi\%20Inoko\%20Hikmasari.pdf
} 


\section{Kajian Pustaka}

Peneliti mempunyai beberapa penelitian terdahulu yang relevan dengan penelitian ini, sebagai berikut:

Pertama, penelitian jurnal berjudul "Merancang Pembelajaran Bahasa Inggris Berbasis Pendekatan Islami” oleh Riza Amelia Dosen Tarbiyah dan Keguruan UIN SUSKA Riau.12 Dalam penelitian ini, beliau menerapkan nilai-nilai islami dalam bahasa Inggris, sehingga nilai-nilai islmai tersebut dapat terbiasa dalam pembelajaran kelas bahasa Inggris. Beliau menambahkan latihan yang mencerminkan nilainilai Islam dalam topik yang diajarkan, masukkan nama-nama orang, tempat, atau acara dalam latihan yang bernuansa Islami; melampirkan Al-Qur'an dan / atau hadits yang relevan; ketika menjelaskan sebuah materi, dan mencampur beberapa ekspresi Islam terkait dengan topik yang diberikan. Penelitian ini juga menambakan campur kode dan alihkode antara ungkapan-ungkapan bahasa inggris dengan ungkapanungkapan khas Islami yang sesuai berdasarkan konteks situasi.

Kedua, Penelitian berjudul "Integrasi Pendidikan Berkarakter dalam Pembelajaran Bahasa Inggris” oleh Astri dan Ria.13 Penelitian ini menerapkan pendidikan karakter bagi Guru TK LPI Nur Hikmah Kampung Sawah. Peneliti menerapkan nilai-nilai pendidikan karakter pada mata pelajaran bahasa inggris. Nilai-nilai karakter tersebut adalah mandiri, kerja keras, rasa ingin tahu, peduli sosial, disiplin, gemar membaca, dan demokratis. Semua nilai- nilai karakter tersebut diterapkan dalam pembelajaran yang ada di TK LPI Nur Hikmah untuk membantu siswa dalam menguasai bahasa Inggris dengan karakter.

\footnotetext{
${ }^{12}$ Riza Amelia, 2012, Merancang Pembelajaran Bahasa Inggris Berbasis

Pendekatan Islami, Jurnal Pemikiran Islam, Vol. 37, No. 1 Januari-Juni, hlm.1, http://ejournal.uin-suska.ac.id/index.php/Anida/article/view/308.

${ }^{13} \mathrm{Rr}$. Astri Indriana Octavita \& Ria Saraswati, Integrasi Pendidikan Berkarakter Dalam Pembelajaran Bahasa Inggris, Jurnal Terapan Abdimas, Vol. 2, hlm. 33-40,
} 
Peneliti menyisispkan pendidikan karakter disana dikarenakan ingin mengajarkan keseharian yang berkarakter sehingga siswa terbiasa dalam karakter tersebut.

Ketiga, Johansyah meneliti tentang "Pendidikan Karakter dalam Islam; Kajian dari Aspek Metodologis" yang meninjau tentang bagaimana pendidikan karakter yang sebenarnya dalam Islam. Faktanya, pendidikan karakter dalam Islam terbentuk dalam hal akhlakul karimah. ${ }^{14}$ Berdasarkan aspek metodologis, metode pembiasaan dan keteladanan adalah cara terbaik untuk pendidikan karakter, yang membiasakan hal yang baik sampai dianggap sebagai budaya dengan pikiran, perasaan dan tindakan. Dan Contoh hal-hal baik untuk siswa sehingga mentransfer nilai ke dalam jiwa mereka, maka itu akan menghasilkan pengetahuan, serta terwujud dalam tindakan.

Berbeda dari penelitian terdahulu, penelitian ini akan memfokuskan pendidikan karakter islam yang diimplementasikan dalam kelas bahasa Inggris. Dengan demikian karakter islami akan masuk kedalam unsur pembelajaran bahasa Inggris dikelas. Sehingga mahasiswa mampu berkarater santun dalam penggunaan bahasa Ingggis di lingkungan dalam maupun luar Universitas Wahid Hasyim.

Penerapan nilai-nilai imlementasi tersebut akan dibantu oleh tutor yang berpengalaman yang akan mengarahkan peserta (dosen) di lingkup Universitas Wahid Hasyim dalam FGD. Sehingga akan tercapai pendidikan karakter islami diseluruh kelas bahasa Inggris yang ada di Universitas Wahid Hasyim.

\footnotetext{
${ }^{14}$ Johansyah 2011. Pendidikan Karakter Dalam Islam; Kajian Dari Aspek Metodologis. Jurnal Ilmiah Islam Futura, Vol. 11; No. 01; 1-26. Retrieved from https://jurnal.ar-raniry.ac.id/index.php/islamfutura/article/view/63
} 


\section{Kerangka Berfikir}

Pendidikan karakter islam yang akan di identifikasi dalam penelitian ini adalah 9 karakter yang sudah dijelaskan dalam teori diatas. Oleh karenanya pendidikan karakter tersebut apakah sudah diterapkan dalam sistem pembelajaran yang ada di Universitas Wahid Hasyim atau belum. Seperti diketahui Universitas Wahid Hasyim adalah universitas yang bermisi ASWAJA yang artinya Ahlussunah Wal Jama'ah yang artinya prinsip yang diterapkan dalam pembelajaran haruslah sama dengan misi tersebut.

Sebagaimana dijelaskan di atas, bahwa Allah telah mengutus Rasullullah SAW untuk memberikan contoh akhlah atau karakter yang baik bagi umat manusia lewat beliau. Sehingga penelitian ini mengambil teori gabungan antara akhlak atau karakter Rasullullah dengan prinsip pendidikan yang dipunyai oleh Ahlussunah Wal Jama'ah NU.

Alasan mengapa menambahkan dengan Ahlussunah Wal Jama'ah karena misi dari Universitas Wahid Hasyim adalah menyebarkan Ahlussunah Wal Jama'ah bagi dosen, karyawan, dan mahasiswa yang ada di lingkup universitas.

Bahasa Inggris adalah bahasa universal yang digunakan diseluruh dunia, selain itu di indonesia, bahasa inggris digunakan sebagai MKU dalam universitas, khususnya Universitas Wahid Hasyim. Sejalan dengan upaya pemerintah untuk memberikan pendidikan karakter yang baik bagi mahasiswa diseluruh nusantara.

Dengan kata lain, peneliti ingin mengetahui sejauh mana pendidikan karakter islam yang ada di Universitas Wahid Hasyim. Apakah pendidikan islam yang dari penggabungan diatas, yaitu 9 poin sudah diterapkan di dalam pembelajaran bahasa Inggris atau belum. Selanjutnya apakah ada nilai-nilai islami lain yang diterapkan ke dalam 
pembelajaran di kelas bahasa Inggris atau belum. Hal inilah yang ingin peneliti kaji tentang Universitas Wahid Hasyim yang notabene mempunya misi Ahlussunah Wal Jama'ah NU. Selanjutnya pemikiran tersebut digambarkan sebagai berikut.

\section{Gambar 1}

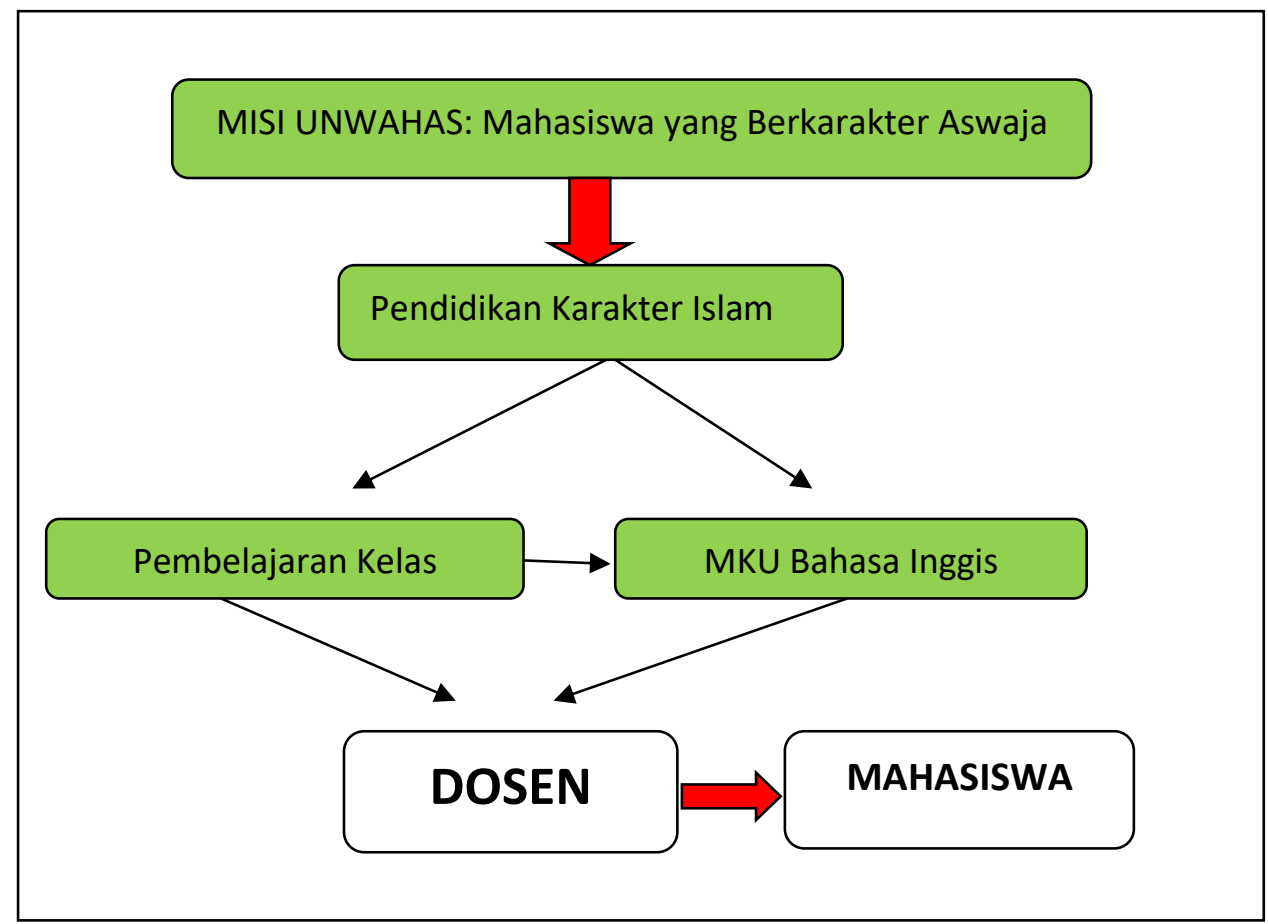

Maksud dari gambar 1 adalah Universitas Wahid Hasyim mempunyai misi universitas yang berkarakter Aswaja. Sehingga pendidikan karakter Islam yang mengacu 9 karakter sangat tepat untuk dimasukkan dalam sistem pembelajaran yang ada pada universitas.

Bahasa Inggris sebagai bagian dari bahasa asing yang wajib diajarkan dalam universitas sebagai MKU akan memberikan dampak budaya barat yang ada pada mahasiswa Universitas Wahid Hasyim. Sehingga pendidikan karakter Islam sangat tepat untuk diterapkan dalam kelas bahasa Inggris supaya mengontrol perkataan dan perbuatan yang tidak sesuai dengan budaya di lingkup Universitas Wahid Hasyim. 


\section{E. Desain Penelitian}

Penelitian ini akan menggunakan pendekatan kualitatif yang mana akan menghasilkan data deskriptif berupa pengamatan perilaku pada subjek yang diberikan FGD. Dalam penelitian ini menggunakan pendekatan kualitatif deskriptif dengan menggunakan jenis penelitian lapangan atau lingkungan alamiah sebagai sumber data langsung. Penelitian lapangan mengungkap fakta kehidupan sosial dan budaya masyarakat di lapangan. ${ }^{15}$ Sehingga pendekatan kualitatif deskriptif adalah pendekatan yang berdasarkan pengamatan lapangan yang menghasilkan data desktiptif berupa perilaku dan ucapan yang akan digunakan sebagai sumber data penelitian secara langsung.

\section{F. Sumber Data}

Arikunto (2006:129) menjelaskan bahwa sumber data adalah subjek asal dari sebuah data. Sumber data dari penelitian ini adalah hasil observasi mahasiswa, hasil interview dosen, dan dokumentasi berupa video dalam pembelajaran MKU Bahasa Inggris di Fakultas Agama Islam Universitas Wahid Hasyim. Terdapat tiga instrumen yang digunakan, diantaranya adalah lembar observasi, lembar interview dan dokumentasi.

\section{G. Tehnik Pengumpulan Data}

Penelitian ini menggunakan metode qualitatif. Terdapat tiga teknik dalam proses pengumpulan data, yaitu observasi, interview dan dokumentasi.

1. Observasi

Pada penelitian ini, penulis menggunakan teknik observasi. Penulis akan mengobservasi tingkah laku mahasiswa selama perkuliahan berlangsung. Dalam proses observasi, penulis

\footnotetext{
${ }^{15}$ Marheni, Metode Penelitian, Jakarta: PT. Bumi Aksara, 2005hlm. 25
} 
menggunakan handycam untuk merekam karakter islami apa yang ditunjukan mahasiswa selama proses perkuliahan. Tujuan dari proses observasi ini adalah untuk mengetahui jenis karakter islami yang dilaksanakan oleh mahasiswa serta apa yang dilakukan dosen untuk selalu mendorong mahasiswa mengimplementasikan karaker islami tersebut. Dalam melaksanakan observasi, penulis menggunakan catatan lapangan. Penulis akan menjelaskan jenis karakter islami yang ditunjukan mahasiswa selama perkuliahan dan bagaimana dosen mendorong mereka untuk konsisten melakukannya. Kemudian, penulis akan menjelaskannya secara menyeluruh. Hal selanjutnya adalah melaksanakan interview kepada dosen dan dokumentasi untuk menunjang data.

\section{Interview}

Interview digunakan dalam penelitian ini sebagai sumber data yang lain untuk mendapatkan informasi secara mendalam. Dalam tahap ini, penulis menginterview dosen pengajar MKU bahasa Inggris untuk mengetahui jenis karakter apa yang menjadi fokus untuk diimplementasikan, tujuan pengimplementasian serta bagaimana cara untuk mendorong karakter tersebut digunakan selama perkuliahan. Sebagai tambahan, penulis akan menginterview mahasiswa yang ikut serta dalam proses perkuliahan tersebut. Hal itu bertujuan untuk mendapatkan informasi tambahan mengenai jenis karakter apa yang mereka lihat, rasakan dan gunakan serta kesan mahasiswa terhadap pengimplementasian karakter tesrsebut. Pada penelitian ini, penulis akan menggunakan alat penunjang pada proses interview dosen dan mahasiswa, diantaranya adalah; kamera dan voice recorder. 
3. Dokumentasi

Pada proses dokumentasi, penulis akan menggunakan handycam untuk merekam kegiatan perkuliahan dan berfokus untuk mengetahui karakter islami selama proses perkuliahan berlangsung. Proses ini akan merekam dan memperlihatkan jenis, cara, situasi, serta respon mahasiswa dalam pengimplementasian karakter islami dalam pembelajaran. Begitu juga dengan langkah dosen pengajar untuk terus mendorong konsistensi pengimplentasian selama pembelajaran.

4. FGD

Kegiatan FGD ini dilakukan untuk menyelaraskan misi pendidikan karakter islam dalam pembelajaran MKU bahasa Inggris yang ada di Universitas Wahid Hasyim. Kegiatan FGD dihadiri dosen MKU bahasa Inggris Universitas Wahid Hasyim. Dalam FGD pertama, peneliti mendiskusikan tentang penerapan pendidikan karakter Islam yang sesuai akhlak nabi dan Aswaja. Sehingga dalam FGD pertama ini, peneliti mendatangkan narasumber dari Aswaja Center untuk memberikan penjelasan dan contoh penerapan pendidikan karakter Islam yang sesuai dengan akhlak nabi muhammad dan Aswaja. Sehingga dosen mempunyai gambaran untuk penerapan yang baik dan benar dalam kelas.

FGD kedua tidak kalah pentingnya dengan yang pertama, dalam kesempatan ini, peneliti mendatangkan narasumber yang memahami akan kelas bahasa inggris dan bagaimana menggabungkan pendidikan karakter Islam dalam kelas bahasa Inggris itu sendiri. Sehingga para dosen MKU bahasa Inggris mengerti akan pentingnya penerapan pendidikan karakter Islam 
tersebut. Selanjutnya dalam FGD kedua ini, para dosen sepakat untuk memberikan sumbangsih dan ide dalam membuat modul yang berdasarkan pendidikan karakter Islam yang sesuai ajaran nabi Muhammad SAW dan Ahlussunah Wal Jama'ah.

\section{H. Tehnik Analisis Data}

Teknik analisi data dalam penelitian ini adalah study kasus qualitative. Penulis akan meggunakan model analisis interview termasuk pengumpulan data, penyederhanaan data, penyajian data serta pengambilan keptusan (Sutopo, 2002:95). 1. Pengumpulan data Pada tahap ini, penulis akan mengumpulkan data dengan menggunkan observasi, interview dan dokumentasi. 2. Penyederhanaan data Pada tahap ini, penulis akan mendapatkan cukup data dari tahap observasi. Kemudian, penulis akan menyederhanakan serta menyajikannya. Dalam penyederhanaan data, penulis akan mengeliminasi data yang kurang berarti atau yang tidak sesuai dengan tujuan penelittian sehingga akan mendapatkan data penting saja. Tujuannya adalah untuk menyederhanakan tanpa kehilangan banyak informasi esensial. 3. Penyajian data tahap selanjutnya dalah penyajian data; hal ini berarti penulis akan menjaikan data secara sistematis dan logis sehingga akan terlihat data yang jelas dan mudah dipahami. Langkah ini akan membantu penulis untuk meningkatkan tingkat validitas data. Penulis menganalisis data dari hasil observasi serta interview. Kemudian, penulis akan menuliskan hasilnya. Pada tahap kesimpulan diharapkan mendapatkan temuan baru yang belum ada pada penelitian sebelumnya. Temuan tersebut menjadi penjelasan dan penggambaran suatu hal yang sebelumnya masih tidak jelas. 4. Penarikan dan verifikasi kesimpulan, Pada akhir tahap pengumpulan data, sebulum menarik kesimpulan, penulis akan mengecek dan mencoba untuk memverifikasi data 
berdasarkan hasil penyederhanaan dan penyajian data. Apabila data tidak lengkap, maka penulis akan mencoba mencarinya. Jika data telah lengkap, penulis akan menarik kesimpulan berdasarkan hasil analisis data yang kemudian dilanjutkan utuk menulis temuan dalam bentuk laporan penelitian.

\section{Validasi Data}

Penulis akan menguji validitas data. Hal ini bertujuan untuk mendapatkan data yang dapat dipertanggungjawabkan dalam proses validsasi. Secara umum terdapat empat karakteristik yang digunkan dalam penelitian qualitatif dalam proses validasi data, yaitu; kredibilitas, transferbabilitas, depenabilitas dan konfirmabilitas. Pada penelitian ini, penulis akan menggunakan kredibilitas karena dapat membuktikan kesesuaian anatara hasil observasi dan fakta di lapangan. Untuk mencapai kredibitas data, penulis akan menggunakan triangulasi. Ini adalah sebuah metode metode yang digunakan oleh peneliti qualitatif untuk mengecek dan membangun validitas dalam penelitiannya dengan menganalisis rumusan masalah dari berbagai perspektif. Terdapat berbagai jenis triangulasi; triangulasi metode, triangualasi peneliti dan triangulasi data. Triangulasi yang akan digunakan dalam penelitian ini adalah triangulasi metode. Penulis menggunakannya karena penelitian ini menggunakan beberapa metode seperti observasi, interview serta dokumentasi. 


\section{J. Hasil Penelitian}

Ada tiga pembahasan hasil penelitian yang merujuk pada rumusan masalah diatas. Ketiga hasil tersebut yang akan dibahas sebagai berikut:

\section{Implementasi nilai-nilai karakter islam dalam kelas MKU Bahasa Inggris di Universitas Wahid Hasyim}

Bedasarkan dari hasil pengamatan (observasi), wawancara, dan kegiatan FGD, peneliti menemukan beberapa pendidikan karakter islam yang diimplementasikan ke dalam pembelajaran MKU Bahasa Inggris. Pendidikan karakter Islam yang diterapkan kepada mahasiswa antara lain:

a. Sidiq

Karakter sidiq disini tercermin dalam perilaku mahasiswa yang diminta dosen untuk mengejakan sesuatu kegiatan.

\section{b. Amanah}

Karakter amanah adalah penggambaran mahasiswa ketika diberikan tugas rumah "take home". Memang tidak semua mahasiswa dalam satu kelas mengerjakan tugas tersebut atau amanah dalam tugas tersebut. Namun kebanyakan mahasiswa amanah ketika diberikan tugas rumahan oleh dosen. Hanya satu atau dua mahasiswa dalam satu kelas yang seperti demikian.

c. Tabligh

Karakter tabligh yang dapat saya gambarkan adalah ketika dosen ada penugasan keluar kota, komting atau ketua diminta dosen untuk menyampaikan tugas dan dikerjakan di kelas untuk selanjutnya segera dikerjakan. Semua komting atau mahasiswa menyampaikan hal tersebut, sehingga tabligh ini adalah karakter 
yang mahasiswa tidak pernah sekalipun tidak menyampaikan apa yang dipesankan atau dititipkan oleh dosen.

\section{d. Fatonah}

Selama observasi berlangsung, peneliti menangkap bahwa kecerdasan dan intelek sudah ada pada diri mahasiswa di Universitas Wahid Hasyim, namun tergantung dengan pengembangan sikap dan kecerdasan itu sendiri.

e. Tasamuh (Toleran)

Sikap toleransi dapat dilihat dari perbedaan karakter dan sikap ketika mahasiswa beradu argumen dalam pendapat di dalam kelas. Namun, tidak tidak satupun mendapatkan mahasiswa beradu argumen dengan sinis.

\section{f. Tawazun (Seimbang)}

Dalam kelas pembelajaran sikap tawazun harus dimiliki setiap mahasiswa, sehingga tidak ada sikap berat sebelah dalam menjalankan tugas atau presentasi. Sebenarnya sikap seperti ini juga berlaku untuk dosen, sehingga dosen mampu berbuat seimbang (adil) dalam menentukan penilaian.

g. Tawasut

Tawasut adalah memberikan jalan tengah atau biasnya dikenal dengan meluruskan. Dalam kelas jika ada perbedaan pendapat antara kedua belah pihak dalam pembelajaran mahasiswa atau dosen berhak menjadi tawasut atau penengah yang mampu memperjelas maksut dan tujuan pembelajaran tersebut.

h. Ta'adul (Keadilan)

Dalam kelas bahasa inggris dosen berlaku adil dengan mahasiswa, cotohnya melakukan perhatian yang sama tanpa memandang status 
sosial dll. Sehingga mahasiswa akan mendapatkan nilai sesuai dengan kemampuannya.

i. Amar ma'ruf Nahi mungkar

Mengajarkan amar ma'ruf nahi mungkar ini sangat sulit memang. Namun sebagian dosen sudah menerapkan ini dalam pembelajaran bahasa Inggris dengan melakukan ujian lisan. Disamping bahasa Inggris memerlukan ujian lisan untuk meninjau kemampuan bahasa Inggris mahasiswanya, disisi lain untuk menghindari percontekan yang sering dilakukan mahasiswa ketika ada tugas individual dalam kelas.

\section{K. Cara dosen MKU Bahasa Inggris mengimplementasikan}

\section{pendidikan karakter islam dalam kelas Bahasa Inggris}

Implementasi pendidikan karakter islam dalam kelas bahasa Inggris tentunya berbeda-beda dari satu dosen ke dosen yang lain. Hal ini dikarenakan metode pembelajaran yang diterapkan dalam setiap dosen berbeda. Sehingga menimbulkan implementasi yang beragam. Implementasi tersebut sebagai berikut:

Hasil dari wawancara setiap dosen MKU Bahasa Inggris menghasilkan berbagai macam implementasi yang berbeda-beda, namun dari perbedaan tersebut terjadi hasil yang sama tentunya. a. Sidiq

Dalam karakter atau akhlak sidiq, dosen meberikan implementasinya dengan mengajarkan tidak berbohong dalam kelas bahasa Inggris. Sebagai gambaran atau contoh adalah dosen memberikan tugas dalam kelas setelah selesai menjelaskan materi, dosen meminta mahasiswa tidak mencontek satu sama lain dalam mengerjakan tugas. 
Selain itu, dosen meminta mahasiswa untuk berkata dengan sebenarnya jika ada mahasiswa yang terlambat dalam masuk kelas. jika ketahuan berbohong, akan ada sanksi yang diberikan terhadap mahasiswa, contohnya tidak diberikan hak absen untuk mahasiswa tersebut setelah tahu berbohong.

Selanjutnya dosen juga mengajarkan contoh dalam bahasa Inggris tentang karakter sidiq, contoh tersebut meliputi dosen meminta sebuah kalimat atau menceritakan tentang apa yg dilakukan setiapharinya dan dituangkan dalam kalimat bahasa Inggris.

b. Amanah

Implementasi karakter ini adalah mahasiswa diberikan tanggung jawab oleh dosen untuk mengerjakan tugas dalam kelas bahasa Inggris. Sehingga mahasiswa dapat bertanggung jawab atas tugas yang diberikan. Selain memberikan tugas, beberapa dosen juga mengajarkan bersikap jujur dalam karakter amanah ini, mengecek satu persatu absensi yang sudah di tanda tangani oleh mahasiswa. Sehingga mahasiswa tidak bisa untuk memalsukan tanda tangan temannya.

Karakter amanah tersebut juga diselipkan dalam pembelajaran dan mengimplementasikannya kedalam cerita dan kalimat dalam bahasa Inggris supaya mahasiswa paham betul bagaimana untuk mengaplikasikan karakter amanah ini.

c. Tabligh

Karakter tabligh diimplementasikan dosen dalam kelas ketika ada mahasiswa yang memberikan jawaban atas tugas yang diberikan. Dosen selalu menyampaikan apakah jawaban mahasiswa benar atau tidak, dan menjelaskan sesuai dengan jawaban. Disini dosen 
mengajarkan sikap tabligh untuk selalu menyampaikan sesuatu dengan apa adanya tanpa mengurangi sedikitpun.

d. Fatonah

Karakter fatonah diimplementasikan oleh dosen untuk memberikan penjelasan yang baik dan tepat sehingga menciptakan mahasiswa yang cerdas dan intelek. Karakter tersebut dibangun dengan menerapkan dan membiasakan mahasiswa untuk mengaplikasikan bahasa Inggris dalam kelas dengan cara mengajak mahasiswa berbicara bahasa Inggris dalam kelas MKU Bahasa Inggris.

e. Tasamuh atau toleransi

Karakter tasamuh/toleransi ditunjukan dengan adanya saling mengahrgai antar suku dan budaya. Selebihnya menghargai pendapat dan pekerjaan orang lain yang berbeda dari mereka.

\section{f. Tawazun}

Karakter tawazun diimplementasikan dosen dengan memperlakukan siswa dengan seimbang dan tidak berat dikanan ataupun di kiri. Karakter tersebut adalah memberikan penialain yang sesuai dengan apa yang dikerjakan dan dilakukan siswa selama perkuliahan berlangsung.

g. Tawasuth

Karakter tawasuth diimplementasikan dosen dengan mengambil jalan tengan ketika ada mahasiswa memberikan asumsi dengan perdebatan yang tidak seharusnya. Disini dosen meluruskan dengan memberikan penjelasan dan gambaran yang jelas dalam pembelajaran dalam kelas.

h. Ta'adul 
Karakter ta'adul adalah karakter yang adil, dosen memberikan sikap adil pada setiap mahasiswa tidak pilih kasih dalam setiap pembelajaran. Ketika mahasiswa berbuat salah dosen menegur dengan memberikan penjelasan yang sesuai. Sebaliknya mahasiswa diminta untuk menegur dosen ketika tidak sesuai apa yang dilakukan.

\section{i. Amar ma'ruf nahi mungkar}

Karakter amar ma'ruf nahi mungkar digambarkan dalam kelas adalah mahasiswa tidak boleh mencontek ataupun meberikan jawaban bahkan plagiasi ketika diberikan tugas dan ujian semesteran.

\section{Pelaksanaan Nilai Karakter Islam dalam Kelas MKU Bahasa} Inggris

Dalam pelaksanaan pendidikan karakter Islam yang ada di Universitas Wahid Hasyim Semarang, seluruh dosen MKU bahasa Inggris telah menerapkan pendidikan karakter Islam dikelas masingmasing. Namun, penerapan pendidikan karakter islam tersebut tidak terarah, maksudnya adalah belum adanya acuan yang harus dipakai untuk menyeragamkan seluruh dosen dalam mengajarkan pendidikan karakter islam di kelas MKU bahasa Inggris. Sehingga setiap dosen pada fakultas yang berbeda memberikan penerapan karakter Islam sesuai dengan apa yang dimengerti oleh dosen tersebut.

Oleh karenanya, dari dosen satu ke dosen yang lainnya hasil penerapan pendidikan karakter dalam kelas bahasa Inggris akan berbeda. Dikarenakan tidak ada acuan pasti dalam menerapkan pendidikan karakter dalam kelas bahasa Inggris. Kemudian atas usul pada acara FGD yang dilaksanakan, forum dosen MKU bahasa Inggris sepakat untuk membuat acuan yang pasti sehingga memberikan dosen bahasa Inggris fokus yang sama dalam sistem mengajar bahasa Inggris dalam kelas. 
Sehingga FGD tersebut menghasilkan sebuah gagasan untuk membentuk modul yang didesain untuk pembelajaran bahasa Inggris dikelas dengan menerapkan pendidikan karakter Islam dengan mengusung akhlak Rasulullah dan misi Universitas yang Ahlussunah Wal Jama'ah.

\section{Pembahasan Penelitian}

1. Implementasi karakter Islami pada Universitas Wahid Hasyim sudah mencakup keseluruhan poin yang dijabarkan. Seluruh poin tersebut diimplementasikan ke dalam pembelajaran yang ada di Universitas Wahid Hasyim. Mahasiswa dan dosen menerapkan seluruh poin tersebut kedalam proses pembelajaran sesuai yang diharapkan.

2. Dosen sebagai pembimbing dalam kelas sudah memberikan sedemikian rupa sehingga dapat terwujud semua poin karakter islam dalam pembelajaran bahasa Inggris, seluruh poin tersebut sudah diterapkan dengan berbeda pandangan. Hal ini dikarenakan tidak semua dosen bahasa Inggris belum tahu tentang misi universitas wahid hasyim, karena sebagian besar dosen MKU bahasa Inggris adalah dosen diluar universitas wahid hasyim. hal ini yang mengakibatkan peneliti memberikan FGD kepada dosen bahasa Inggris dilingkup Universitas Wahid Hasyim, sehingga kedepannya dapat memberikan sinergi yang sama atau memberikan kontribusi dalam pembelajaran yang sama sesuai dengan misi universitas. Adapun diskusi FGD tersebut menghasilkan beberapa poin yang disepakati:

a. Pertemuan sebelum sks MKU bahasa Inggris diajarkan, hal ini untuk mendiskusikan bagaimana penerapan karakter islam yang baik bagi mahasiswa dalam kelas Bahasa Inggris. Ini akan 
difasilitasi unit bahasa universitas yang selama ini tidak terlalu aktif dalam pembinaan dosen bahasa Inggris.

b. Bertukar informasi ketika menemukan gagasan baru untuk pembelajaran bahasa Inggris yang ada di Universitas Wahid Hasyim

c. Membuat Modul yang seharusnya disesuaikan dengan kondisi Universitas Wahid Hasyim.

Pelaksanaan pendidikan karakter islam di universitas wahid hasyim sudah diimplementasikan semua, namun butuh keselarasan dalam penyampaiannya. Khususnya untuk menyeragamkan persepsi pendidikan karakter islam dalam kelas bahasa inggris. Kepekatan dibuat dalam acara FGD adalah untuk membuat modul yang berdasar pada pendidikan karakter yang sesuai universitas.

\section{N. Simpulan}

Berdasarkan pembahasan yang telah dipaparkan pada bab sebelumnya dapat disimpulkan bahwa hasil penelitian menunjukkan bahwa:

1. Aplikasi pendidikan karakter Islam dalam kelas bahasa Inggris yang ada di Universitas Wahid Hasyim semarang sudah memenuhi 10 poin.

2. Dosen sudah menerapkan ke 10 poin tersebut dalam pembelajaran Bahasa Inggris dalam kelas. namun tidak semua dosen mengaplikasikan poin tersebut, ada satu poin yaitu religius yang hanya digunakan 2 fakultas yang ada di Universitas Wahid Hasyim 


\section{DAFTAR PUSTAKA}

Dr. Arie Budhiman, 2017, Gerakan Penguatan Pendidikan Karakter, Jakarta:

Kementerian Pendidikan dan Kebudayaan Republik Indonesia.

Inoko Hikmasari, 2012, Pemahaman Bahasa Inggris oleh siswa Kampung

Inggris, Jurnal Universitas Unair, Vol.1, No. 1 Januari-Juni, hlm.4_http://journal.unair.ac.id/download-fullpapers-

jurnal\%20skripsi\%20Inoko\%20Hikmasari.pdf

Johansyah, 2011. Pendidikan Karakter Dalam Islam; Kajian Dari Aspek Metodologis. Jurnal Ilmiah Islam Futura, Vol. 11; No. 01; 1-26. https://jurnal.ar-raniry.ac.id/index.php/islamfutura/article/view/63

Marheni, 2005, Metode Penelitian, Jakarta: PT. Bumi Aksara.

Masnur Muslich, 2011. Pendidikan Karakter Menjawab Tantangan Krisis Multidimensional, Jakarta: Bumi Aksara.

Riza Amelia, 2012, Merancang Pembelajaran Bahasa Inggris Berbasis Pendekatan Islami, Jurnal Pemikiran Islam, Vol. 37, No. 1 JanuariJuni, hlm.1, http://ejournal.uinsuska.ac.id/index.php/Anida/article/view/308.

Rr. Astri Indriana Octavita \& Ria Saraswati, Integrasi Pendidikan Berkarakter Dalam Pembelajaran Bahasa Inggris, Jurnal Terapan Abdimas, Vol. 2, hlm. 33-40,

Saddhono, K. 2014. Pengantar Sosiolingistik Teori dan Konsep Dasar. Surakarta: UNS Press.

Zamroni, 2000, Paradigma Pendidikan Masa Depan, Jogjakarta: Gigraf Publishing. 